\title{
The Development of PKn Learning Media in the Form of Microsoft Power Points on the Material on the Diversity of Individual Characteristics of Class III SD/MI
}

\author{
Luh Mela Indayani ${ }^{1 *}$, Anak Agung Gede Agung ${ }^{2}$, Kadek Yudiana $^{1}$ \\ ${ }^{l}$ Primary School Teacher Education Study Program, Majori In Basic Education, Universitas Pendidikan Ganesha, \\ Indonesia \\ ${ }^{2}$ Education Technology Study Program, Majori In Education Science, Psychology and Guidance, Universitas \\ Pendidikan Ganesha, Indonesia \\ *Corresponding author. Email: mellaindayani23@gmail.com
}

\begin{abstract}
This study aims to develop learning media for microsoft power point that can be used as an innovative learning medium in Civics lessons at SD N 1 Banjar Bali. With learning media in the form of power points, this makes students more interested and active in learning in the classroom. This research used the Borg and Gall model of research and development (R\&D) which was carried out in only six stages because school conditions were not conducive due to the Covid-19 pandemic so that it could not be tested in the field and only reached the sixth stage. The steps taken are (1) analysis of potentials and problems, (2) data collection, (3) product design, (4) design validation, (5) design revision and (6) individual trials. The evaluation of the development of learning media in the form of power points was assessed by 3 expert validators, namely (1) content expert test, an average score of $92 \%$ was obtained in the very feasible category, (2) the instructional design expert test obtained an average score of $93 \%$ being at very feasible category and (3) media expert test obtained an average score of $92 \%$ in the very feasible category. While the media test subjects were only carried out in the individual test stage, namely 3 students who were drawn from high, moderate, and low abilities, it was obtained an average of $93 \%$ who were in the very feasible category.
\end{abstract}

Keywords: Learning Media, Power Points, Diversity of Individual Characteristics

\section{INTRODUCTION}

Everyone has rights and obligations, one of which is the right to get education. With the existence of education, it is hoped that it can form human resources with character and character. Education is important in building a nation's civilization. Through education, it is hoped that the quality of the Indonesian people will increase. In Law Number 20 of 2003 concerning the National Education System Article 1 states that education is a conscious and planned effort carried out to create an atmosphere of learning and the learning process so that students are actively involved in developing their potential to have self-control, intelligence and skills that are needed for themselves, society, nation and state.

Education must continue to be developed towards the direction of improving the quality of education. Quality education can provide opportunities for humans to be able to develop all their potential. To improve the quality of education, it must be carried out in a sustainable and comprehensive manner. This is a challenge for the government to keep trying to improve and develop the quality of education for the better and achieve the stated goals. As for the efforts made by the Indonesian government, namely, by procuring textbooks, refining the curriculum, improving the learning process, and other efforts related to the quality and quality of education. However, the facts in the field have not shown satisfactory results, one of which is at the primary school level.

Education at the Elementary School level is a very important foundation to equip students to move on to the next level of education. Every lesson given at this level of education leads to the formation of a strong academic 
foundation for students. One of the learning processes provided at the primary school level as contained in Law Number 20 of 2003 Article 37 is Citizenship Education (Civics).

Civics is "a scientific discipline that studies the nature of citizenship, both in the concept of the relationship between citizens and the state, rights and obligations and the government system of a country that is run by citizens" [1]. Civics are actually practiced and developed throughout the world, although with various terms or names. Civics have a strategic role in preparing smart and responsible citizens [2]. Civics learning is very important to be given to students at the basic education level. One of the goals of Civics is "to prepare students to become smart and good citizens in accordance with Pancasila values" [14]. In Civics learning, a learning media is needed to support the continuity of the learning process and make it easier for students to understand the material presented. Therefore, teachers should strive to create a creative, innovative, effective and fun learning process so that the learning atmosphere becomes more conducive.

According to [3] learning media is anything that is used to transmit messages or material from teachers to students so that it can stimulate students' thinking, attention and interest in participating in learning activities. Meanwhile, according to [4] learning media is a way that teachers use to convey and clarify material to achieve learning objectives. Through the use of media, the teacher will find it easier to convey messages or materials.

Gerlach and Ely in [5] suggest three characteristics of media based on instructions for using learning media. The three characteristics or characteristics of the learning media are a) fixative, which describes the media's ability to record, store, preserve and reconstruct an event or object; b) manipulative characteristics, namely the ability of the media to transform an object, event or process in overcoming the problem of space and time; c) distributive characteristics that describe the ability of the media to transport objects or events through time and space simultaneously, the incident is presented to a large number of students, in various places, with a relatively short stimulus of experience regarding the incident.

Learning media can be classified into several classifications depending on the point of view. Media classification according to Bretz's taxonomy is grouped into 8 categories, namely: 1) motion audio visual media, 2) silent audio-visual media, 3) semi-motion audio media, 4) motion visual media, 5) silent visual media, 6) semi-motion media , 7) audio media, and 8) print media. Unlike Bretz, without mentioning the type of each medium, Gagne made 7 types of media grouping, namely objects to be demonstrated, oral communication, print media, still images, motion pictures, sound films, and machine learning.
The use of learning media has a great influence on the sustainability of the learning process, this is because the function of the learning media is as a means to create a more effective learning situation, besides that the learning media also functions as a way to accelerate the learning process. According to [6] conveying the function of learning media in general, namely clarifying the presentation of messages so that they are not too visual, overcoming the limitations of time, space and senses, increasing interest and attracting student attention. While the benefits of learning media according to [7] are that media can foster student learning motivation, the material presented will be clearer, teaching methods will be more varied, and students will do more activities during learning activities so that later it will make it easier for students to equalize perceptions.

Some of the reasons people choose media include wanting to give a more concrete picture or explanation, feeling familiar or accustomed to using media in the learning process, and feeling that media can be used to attract students' interest and attention in participating in learning activities. Media selection criteria must be developed in accordance with the objectives to be achieved, the existing conditions and limitations by considering the capabilities and characteristics of the media used [6]. In addition to paying attention to the nature of the media, media selection is also influenced by other factors such as student characteristics, teaching and learning strategies, material to be presented, sources and assessment assessments are also considered.

Jalinus [5] states that in the selection of learning media there are several considerations or criteria that can be used in order to fulfill needs and achieve learning objectives. General criteria that need to be considered include (1) learning objectives, (2) conformity with the material, (3) student characteristics, (4) student learning styles (audio, visual, and kinesthetic), (5) environment, and (6) availability of supporting facilities. So it can be concluded that the selection of the media is carried out more thoroughly by considering several influencing factors.

Based on the results of interviews conducted with class III teachers at SD Gugus VII, Buleleng District on Wednesday, October 23, 2019, it is known that (1) there are still many students who experience difficulties and are less interested in the Civics learning process, (2) lack of interaction or cooperation among students Civics learning process. In addition, based on the results of observations made at SD Gugus VII, Buleleng District on Wednesday, October 23, 2019, it is known that (1) tend to still use lecture and assignment methods, (2) lack of use of innovative learning models and media.

Learning activities like what has been conveyed above have an impact on the lack of enthusiasm and interest of students in participating in learning, especially in Civics subjects. This causes students to be less active 
in the classroom during the learning process, therefore it is necessary to develop more attractive learning media to support the learning process. One of the media that can attract and help students to make it easier to understand the material being taught is Microsoft Power Point media.

Microsoft PowerPoint is an application program that was created with the aim to support and to assist everyone in making presentations. According to Astawan [8] Microsoft Power Point is a software that will help compile an effective, professional and easy presentation. Meanwhile, according to [9] Microsoft Power Point is a software created and developed by the Microsoft company, and is a multimedia-based program. This program is specifically designed to deliver presentations, whether organized by companies, government, education, or individuals, with a variety of menu features that can make it an attractive communication medium. The advantages of PowerPoint itself are that they are easy to use, and have an attractive appearance. Some of the things that make this media interesting to use as a presentation tool are the various text, color and image processing capabilities, as well as animations that can be processed independently of the user's creativity.

Users of this program also have the following advantages: 1) The presentation is attractive because there are games of color, letters and animation, both text animation and animated images or photos. 2) More stimulating children to find out more information about the teaching materials presented. 3) Information messages are visually easy for students to understand. 4) Educators do not need to explain much of the teaching materials that are being presented. 5) Can be reproduced as needed, and can be used repeatedly. 6) Can be stored in the form of optical or magnetic data. (CD / Diskette / Flashdisk), making it practical to carry everywhere [9]. The use of microsoft power point media during learning is expected to be more able to arouse enthusiasm in participating in learning and help students more easily understand their own knowledge. Thus the learning material delivered is easily understood by students. This can also make students interested and active in the learning process, so that the teaching and learning process goes as expected.

Based on the background described above, the authors wish to conduct a study entitled Development of Civics Learning Media in the form of Microsoft Power Points on the Diversity of Individual Characteristics of Class III SD / MI.

\section{METHOD}

This type of research is development research or what is known as Research and Development (R\&D). The research steps used in this study were the development procedure according to Borg and Gall. In full, according to Borg and Gall, there are 10 steps for implementing the
Research and Development (R\&D) strategy, namely (1) potential and problems, (2) data collection, (3) product design, (4) design validation, (5) design revision, (6) product testing, (7) product revision, (8) usage trial, (9) product revision, (10) mass product. In this development research, only five development steps are carried out to produce a product. The research did not reach product trials due to ineffective school conditions due to the Covid-19 pandemic, in this development only knowing whether this product is feasible or not.

The data collection method used in this research on the development of learning media products for Microsoft Power Point uses the questionnaire method. The instrument used in this study was a questionnaire sheet. The questionnaire sheet is used as a guide for the validator in assessing the quality and feasibility of the Microsoft Power Point learning media product that will be developed. The questionnaire sheet will be filled in by 1 content expert, 1 instructional design expert and 1 media expert according to their expertise in the field of Civics subjects. The results of validation that have been carried out by expert validators are used as input and revision of the developed learning media.

The data analysis technique in this study is to describe all opinions such as suggestions and all responses from the evaluators in the comments column. In the trial phase, data were collected using an open assessment questionnaire to provide criticism, suggestions, input and improvements. The results of this descriptive analysis are used to determine the development results in the form of power points. In this study, the analysis used was percentage descriptive analysis. This percentage descriptive calculation has steps, namely (a) counting the number of respondents, (b) correcting the questionnaire answers from the respondents, (c) calculating the frequency of respondents' answers, and (d) entering into the formula. This percentage descriptive calculation is processed with the following formula [10].

$$
P=\frac{f}{n} x 100 \%
$$

Information:

$$
\begin{aligned}
& \mathrm{P}=\text { percentage } \\
& \mathrm{n}=\text { the maximum number of frequencies/scores } \\
& \mathrm{f}=\text { the frequency of answer/scores obtained }
\end{aligned}
$$

The data analysis technique is in the form of media and material expert product evaluation using product assessment criteria. Product assessment criteria are used to determine the classification of development products. The product assessment criteria used are as follows [10]. 
Table 1. Product Assessment Criteria

\begin{tabular}{|c|c|c|}
\hline $\begin{array}{c}\text { Interval } \\
\text { Percentage Level } \\
\text { of Achievement }\end{array}$ & Score & Qualification \\
\hline $85 \%-100 \%$ & 5 & Very Worthy \\
\hline $75 \%-84 \%$ & 4 & Worth it \\
\hline $60 \%-74 \%$ & 3 & Decent Enough \\
\hline $40 \%-59 \%$ & 2 & Less Feasible \\
\hline $0 \%-39 \%$ & 1 & Very Less Feasible \\
\hline
\end{tabular}

\section{RESULTS AND DISCUSSION}

The research and development of this media was carried out with a development procedure according to Borg and Gall which was carried out in six stages due to the unfavourable school conditions. The potential in this research and development is in the form of Microsoft power point media on the material on the diversity of individual characteristics of class III SD / MI. The problem in this research and development is that the use of learning media in the learning process is still less varied so that students become bored quickly in participating in learning activities.

After the potentials and problems are resolved, information data is collected. Information gathering is very important to do to find out the needs of students for the products that will be developed in this study. The first stage is to collect information obtained through interviews with educators in Cluster VII, Buleleng District on 23 October 2019. The next step is to collect reference sources to support the development of learning media in the form of Microsoft power points at the SD / MI level. Reference sources for developing learning media are obtained from information sources in the form of books, journals and the internet.

After collecting the data obtained through interviews with educators and then supported by information from books, journals and the internet, the next step is to design a learning media product in the form of Microsoft power point material on the diversity of individual characteristics of class III in SD / MI. The steps taken by researchers in this stage of learning media development are (1) collection, selection and selection of teaching materials and materials, (2) determining the number of slides to be used in advance, adjusting to the material that has been selected, (3) selecting and collecting secondary learning media such as learning pictures and videos, (4) determining the background and inserting the selected learning materials, images, and videos, (5) creating animations and hyperlinks on each material or slide.

This product was validated by 3 expert validators, namely: Mr. Alexander Hamonangan Simamora, SE, M.Pd., Ms. Ni Wayan Eka Widiastini, S.Pd., M.Pd., And Ms. Ni Luh Sarini, S.Pd. Stage This validation is an important stage because through this stage the researcher can find out the feasibility of the learning media made before being tested. Based on the acquisition of values and comments regarding the strengths and weaknesses and suggestions for improvement at the validation stage by media and material expert lecturers, the learning media developed needs to be revised or improved to make it better. After the validation stage is carried out, the researcher can find out how feasible the learning media that has been designed to be tested. The next stage is the revision stage or improving the learning media design according to the suggestions and criticisms that have been given by the expert validator. The results of the validation provide information to researchers regarding weaknesses in the media being developed.

Learning media in the form of Microsoft power points on the material on the diversity of individual characteristics of class III SD / MI has been developed by researchers. This product development research is carried out by collecting data or information, designing products, validating tests and revising designs. The goal to be achieved in developing this product is to produce learning media that are innovative and suitable for use during the learning process. The development of learning media in the form of power points is presented with an attractive appearance in order to attract the attention of students in learning. Products developed by researchers are expected to help students to be more active in class.

The evaluation of the development of learning media in the form of power points was assessed by 3 expert validators. Based on the data in table 4.3 , it is obtained that the media expert's assessment is $93 \%$, the instructional design expert's assessment is $92 \%$ and the content expert's assessment is $92 \%$ so that the average of the three is $92.3 \%$. The results of media validation by expert validators after revision are in table 2 as follows.

Table 2. The Result of Media Validation by Expert Validators After Revision

\begin{tabular}{|c|l|c|c|c|c|}
\hline No & Validator & $\begin{array}{c}\text { Total } \\
\text { Score }\end{array}$ & $\begin{array}{c}\text { Score } \\
\text { Max }\end{array}$ & $\begin{array}{c}\text { Percen- } \\
\text { tage }\end{array}$ & $\begin{array}{c}\text { Cate- } \\
\text { gory }\end{array}$ \\
\hline 1 & $\begin{array}{l}\text { Instructional } \\
\text { Design } \\
\text { Expert }\end{array}$ & 93 & 100 & 93 & $\begin{array}{c}\text { Very } \\
\text { Worthy }\end{array}$ \\
\hline 2 & $\begin{array}{l}\text { Content } \\
\text { Expert }\end{array}$ & 92 & 100 & 92 & $\begin{array}{l}\text { Very } \\
\text { Worthy }\end{array}$ \\
\hline 3 & Media Expert & 92 & 100 & 92 & \\
\hline \multicolumn{2}{|c|}{ Amount } & 277 & 300 & 92.3 & $\begin{array}{l}\text { Very } \\
\text { Averthy }\end{array}$ \\
\hline
\end{tabular}


In accordance with table 2 above, the learning media in the form of a power point is stated in very feasible criteria, this is reinforced by the assessment of 3 expert validators who state that the product that has been developed is feasible in the assessment and is worthy of being tested.

After going through the validation stage, the media developed was then tested on students. This trial aims to get responses, input, criticism and suggestions from students. At this stage the product will be tested on an individual basis for 3 students drawn from high, medium, and less than one school abilities. Based on the results of the trials conducted, it was obtained an average of $93 \%$ and was categorized as very feasible.

\section{CONCLUSION}

This learning media product development research uses a product development model that refers to the theory of Borg and Gall which has been adapted by researchers according to the needs of the object and research subject. The main procedures used by researchers are potential problems, collecting data, product design, design validation and design revision.

This research and development is in the form of Microsoft power point media on the material on the diversity of individual characteristics of class III SD / MI. The problem in this research and development is that the use of learning media in the learning process is still less varied so that students become bored quickly in participating in learning activities. Therefore, researchers will develop learning media in the form of power points as one of the learning media so that students are more active in the learning process and do not get bored quickly. Furthermore, information data collection is carried out. The first stage is to collect information obtained through interviews with educators in Cluster VII, Buleleng District on 23 October 2019. The next step is to collect reference sources to support the development of learning media in the form of microsoft power points at the SD / MI level.

After collecting the data obtained through interviews with educators and then supported by information from books, journals and the internet, the next step is to design a learning media product in the form of microsoft power point material on the diversity of individual characteristics of class III in SD / MI. the next stage is the validation stage, this validation stage is an important stage because through this stage the researcher can find out the feasibility of the learning media made before being tested. In addition, the score (score) and comments on the strengths, weaknesses and suggestions for improvement from the validator will determine whether the media created needs to be revised or not.

The evaluation of the development of learning media in the form of power points was assessed by 3 expert validators. Based on the data in table 4.3 , it is obtained that the media expert test assessment is $93 \%$, the instructional design expert test assessment is $92 \%$ and the content expert test assessment is $92 \%$ so that the average of both is $92.3 \%$. In accordance with table 4.3 , this learning media in the form of a power point is stated in very feasible criteria, this is reinforced by the assessment of 3 expert validators who state that the product that has been developed is feasible in the assessment and is worth testing.

After going through the validation stage, the media developed was then tested on students. This trial aims to get responses, input, criticism and suggestions from students. At this stage the product will be tested individually for 3 students drawn from high, medium, and less than one school abilities. Based on the results of the trials conducted, it was obtained an average of $93 \%$ and was categorized as very feasible. After going through a series of research activities, the researcher made several suggestions that need attention. For Users of Learning Media Products To utilize learning media in the form of power points, users are advised to use a computer that contains the Microsoft PowerPoint application. In addition, the basic ability to use Microsoft PowerPoint must also be owned in order to be able to smoothly use this media.

Suggestions for educators should be more creative in managing learning media, methods and techniques in Civics learning in order to arouse students' interest in learning. Suggestions for other researchers should continue and re-develop learning media like this with a wider scope and use a more complex program.

\section{ACKNOWLEDGMENT}

This work was supported by Ganesha University of Education (Undiksha), Faculty of Education (FIP), Department of Basic Education, Primary School Teacher Education Study Program (PGSD).

\section{REFERENCES}

[1] E. Nurhayati, The Influence of Non Example Example on Learning Outcomes of Civics Class IV Min Bangka Belitung, Journal of Education and Learning, 6 (9), 2017.

[2] Kaelan, Civic education, Jakarta: Paradigm, 2012.

[3] A. Sudrajat, Learning Media, Learning Media, 1997.

[4] D. Nurhidayanti, Making Learning Media Based on Power Point and Utilizing Android Applications for Arabic Teachers, Karinov Journal, Vol. 2, No. 3, 2019.

[5] N. Jalinus, Media and Learning Resources, Jakarta: Golden, 2016. 
[6] A. Sadiman, Educational Media, Depok: Rajawali Press, 2012.

[7] L. Agustin, Utilization of Microsoft PowerPoint as an Alternative Media for Learning Mathematics in Elementary Schools, In Proceedings of the Seminar and Discussion on Basic Education, Journal UNJ, 2018.

[8] S. D. Putra, The Effect of Snowball Throwing Cooperative Learning Model Aided by Power Point Media on Science Learning Outcomes, Undiksha PGSD Mimbar Journal, Vol. 5, No. 2, 2017.

[9] Santoso. The Influence of Using Power Point Media on Social Studies Achievement of Class V Students of SDN Godean 2 Sleman Academic Year 2017/2018. PGSD Study Program, PGRI University Yogyakarta, 2019.

[10] M. E. Kurniati, Development of Media and Indonesian Language Learning Materials with Microsoft Power Points for Class VIII Semester 2 Students of SMP Marganingsig Muntilan, Thesis, Sanata Dharma University, https://repository.usd.ac.id/6478/, 2016. 